\title{
THE TOXIC MIXING ZONE OF NEUTRAL AND ACIDIC RIVER WATER: ACUTE ALUMINIUM TOXICITY IN BROWN TROUT (Salmo trutta L.)
}

\author{
P.M. VERBOST ${ }^{1}$, M.H.G. BERNTSSEN ${ }^{1}$, F. KROGLUND ${ }^{2}$, E. LYDERSEN ${ }^{3}$, H.E. \\ WITTERS ${ }^{4}$, B.O. ROSSELAND ${ }^{3}$, B. SALBU ${ }^{5}$ AND S.E. WENDELAAR BONGA ${ }^{1}$ \\ 1. Department of Animal Physiology, University of Nijmegen, NL-6525-ED Nijmegen, The Netherlands \\ 2. Norwegian Institute for Water Research, Televn. 1, 4890 Grimstad, Norway \\ 3. Norwegian Institute for Water Research, Kjelsås $\mathrm{N}-0411$, Oslo, Norway \\ 4. VTTO, Radioprotection Department, Boeretang 200, B-2400 Mol, Belgium \\ 5. Laboratory for Analytical Chemistry, Agricultural University of Norway, N-1432 As, Norway
}

\begin{abstract}
Mixing of acid river water containing aluminium (pH 5.1, Al $345 \mu \mathrm{g} \cdot \mathrm{l}^{-1}$ ) with neutral water of a lake (pH 7.0, Al $\left.73 \mu \mathrm{g} . \mathrm{l}^{-1}\right)$ resulted in water ( $\left.\mathrm{pH} 6.4, \mathrm{Al} 245 \mu \mathrm{g} . \mathrm{l}^{-1}\right)$ with a $\mathrm{pH}(6.4)$ and $\mathrm{Al}$ concentration $\left(245 \mu \mathrm{g} . \mathrm{l}^{-1}\right)$ expected to have low toxicity to fish on the basis of current Al toxicity models. However, under semi-field conditions the freshly mixed water (a few sec. after mixing) proved to be highly toxic to brown trout. The fish were exposed to the water at different places along a $30 \mathrm{~m}$ channel. At the beginning of the channel acid and neutral water were continuously mixed; the mixed water left the channel after $340 \mathrm{sec}$. The cells of the gills showed a highly increased rate of cell death by apoptosis and necrosis. Intercellular spaces were enlarged, and many leucocytes penetrated in these spaces. Mucus release was stimulated to depletion. Plasma chloride levels were hardly affected. There was a clear gradient in the deleterious effects on the fish along the channel. The fish at the beginning of the channel (about $12 \mathrm{sec}$. after mixing of the water), were severely affected, whereas the fish kept at the end of the channel $(340 \mathrm{sec}$. after mixing) were only mildly affected. In the natural situation fish will relatively quickly pass through a mixing zone. In our study we therefore focused on the effects on fish after a $60 \mathrm{~min}$ exposure to a mixing zone ( $5 \mathrm{sec}$ after mixing), with subsequent recovery in a region downstream of the confluence and in neutral water with low Al. The recovery in the downstream area (at the end of the channel, i.e. 5 min after mixing) was clearly hampered when compared to the recovery in neutral water with low aluminium. Thus, a short exposure to the toxic mixing zone followed by a stay in water downstream of this zone, as may occur in nature, is detrimental to migrating trout. We conclude that freshly mixed acid and neutral water contain toxic components during the first seconds to minutes after mixing, that can not be explained by current models on aluminium toxicity.
\end{abstract}

Keywords: aluminium toxicity, non-equilibrium chemistry, $\mathrm{pH}$, stress, apoptosis, necrosis, trout.

\section{Introduction}

Fish mortality has been reported in areas where acid, Al-containing water mixes with neutral (limed water) even though the mixed medium typically has a $\mathrm{pH}$ above that known to produce toxic aluminium (Al) species $(>\mathrm{pH} 5.5$; Muniz and Leivestad, 1980; Baker and Schofield, 1982; Howells et al., 1983, Verbost et al. 1992). In field experiments with Atlantic salmon and brown trout, higher mortality has been observed in the mixing zone ( $0-20 \mathrm{sec}$ after mixing of water of an acid inlet with that of a neutral lake) than in the acid inlet, which has been attributed to transient products of Al-polymerization (Rosseland et al., 1992; Poleo et al., 1994). In this study we aimed to gain more insight in the toxic effects of such mixing zones on brown trout by electron microscopy of the gills in combination with measurements of plasma $\mathrm{Cl}^{-}$levels and blood haematocrit. In an artificial channel neutral water and acid water, coming from two lakes, were mixed and led through the channel with a maximum water residence time of $340 \mathrm{sec}$. Brown trout were exposed for up to $72 \mathrm{~h}$ to the mixed water at different sites along the channel.

Water, Air and Soil Pollution 85: 341-346, 1995.

(C) 1995 Kluwer Academic Publishers. Printed in the Netherlands. 
In addition to the long term exposure experiments intended to demonstrate the toxicity of the mixing zone, we studied a more natural situation where the fish relatively quickly pass through the toxic mixing zone. The fish are known to try to escape from toxic mixing zones if they can (Åtland and Barlaup, 1995). This field study focused on the effects of a relatively short exposure $(60 \mathrm{~min})$ of brown trout to a toxic mixing zone, with and without subsequent recovery in a region down stream of the toxic zone and in neutral water with low $\mathrm{Al}$.

\section{Materials and methods}

Fish. Brown trout (Salmo trutta), 5 to $14 \mathrm{~g}$ in weight $(8 \pm 2 \mathrm{~g}, \mathrm{n}=80)$, were obtained from the Oslomarkas Fish Administration (OFA) hatchery near Oslo, Norway. Fish were transferred to the experimental site ( $1 \mathrm{~h}$ by road) and were kept in a large tank until being used in the experiment.

Experimental design. The mixing zone experiments were performed in a Y-shaped channel (Poleo et al. 1994) in the respective arms of which water was pumped from lake Nepptjern (pH 5.1, Al $345 \mu \mathrm{g} . .^{-1}, \mathrm{Ca} 20 \mu \mathrm{mol} .1^{-1}$ ) and lake Gorja (pH 7.0, Al $73 \mu \mathrm{g} .1^{-1}, \mathrm{Ca}$ $\left.160 \mu \mathrm{mol}^{-1} \mathrm{I}^{-1}\right)$, located in the Nordmarka area north of Oslo. From the point of confluence (where thorough mixing was assured resulting in water of $\mathrm{pH} 6.4$, Al $245 \mu \mathrm{g} .1^{-1}$, Ca 77 $\left.\mu \mathrm{mol} . \mathrm{I}^{-1}\right)$ to the end, the channel was $30.5 \mathrm{~m}$ long. The channel was $20 \mathrm{~cm}$ wide and 15 $\mathrm{cm}$ deep, the flow rate was around $9 \mathrm{~cm} \cdot \mathrm{sec}^{-1}$ corresponding with $340 \mathrm{sec}$ residence time of the water. Fish were kept in cages at various intervals along the channel and protected from direct light by covers. Control groups were put in cages in the two inlet arms in front of the mixing zone. Separate cages, with fish that were not sampled, were used for determining mortality.

For the recovery experiment fish were exposed to the toxic mixing zone $(5 \mathrm{sec}$ after mixing) for $60 \mathrm{~min}$ and subsequently moved to either the far end of the channel (in water aged for $340 \mathrm{~min}$, cage $\mathrm{W}$ ) or to separate black tanks with neutral, unmixed water (from lake Gorja) which provided optimal recovery conditions. As controls for the exposure and the handling, fish were held for $60 \mathrm{~min}$ in the neutral and acid water inlets and cage $\mathrm{W}$, and subsequently transferred to either cage $\mathrm{W}$ or a black tank with water from lake Gorja. Experiments were conducted in June 1994.

Electron Microscopy. Gill samples were obtained from the third gill arch on the left side. Tissues were fixed in $3 \%$ glutaraldehyde buffered in sodium cacodylate $\left(0.1\right.$ mol. $.^{-1}, \mathrm{pH}$ 7.3 ), and post-fixed in $1 \%$ osmium tetroxide in the same buffer. Ethanol-dehydrated tissues were embedded in Spurr's resin. Ultrathin sections, collected on 150 mesh copper grids, were contrasted with uranyl acetate and lead citrate. They were examined in a Jeol 100 CXII transmission electron microscope.

Analytical techniques. Total acid reactive $\mathrm{Al}\left(\mathrm{Al}_{\mathrm{r}}\right)$ was measured after acidifying untreated water samples to $\mathrm{pH} 1.0(\mathrm{HCl})$ for at least $24 \mathrm{~h}$ before the Barnes-Driscoll extractioncation exchange method (Driscoll, 1984) was applied to measure Al. 
Blood from samples collected from the caudal vessels after cutting the tails was partly used for determination of haematocrit (heparinized capillaries were filled, centrifuged and read). The other part was centrifuged in heparinized eppendorfs and plasma transferred to clean tubes. Plasma chloride was determined in the field (with a chloride titrator) and checked, with similar results in the laboratory (automated colorimetric method according to Zall et al., 1956).

\section{Results}

\section{Plasma chloride and blood haematocrit}

In fish from cage $\mathrm{Ne}$, receiving water from the acid inlet from Lake Nepptjern,

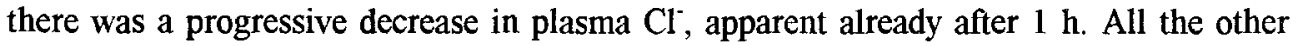
groups showed no significant changes in plasma $\mathrm{Cl}^{-}$during the long exposure experiment except for group E ( $5 \mathrm{sec}$ after mixing) after $24 \mathrm{~h}$ (Table 1).

Table 1

Top: Effects on plasma $\mathrm{Cl}^{-}$and haematocrit of brown trout of exposure for $1 \mathrm{~h}$ or $24 \mathrm{~h}$ to neutral, unmixed water with low $\mathrm{Al}$ (Go; neutral inlet of channel), to acid water with high $\mathrm{Al}$ ( $\mathrm{Ne}$; acid inlet of channel), to the confluence of both water types (E; beginning of channel, $5 \mathrm{sec}$ after mixing), or to mixed water $340 \mathrm{sec}$ after mixing ( $\mathrm{W}$; end of channel).

Bottom: Effects on plasma $\mathrm{Cl}^{-}$and haematocrit of recovery for $24 \mathrm{~h}$ (after $1 \mathrm{~h}$ exposure to water of the mixing zone, E) in tanks with neutral water from Lake Gorja (GoT) or to mixed water at the end of the channel $(W)$.

\begin{tabular}{|c|c|c|c|c|}
\hline & Go & $\mathrm{Ne}$ & $E$ & W \\
\hline $\begin{array}{l}\text { plasma } \mathrm{Cl}^{-} 1 \mathrm{~h} \\
\text { plasma } \mathrm{Cl}^{-} 24 \mathrm{~h}\end{array}$ & $\begin{array}{l}121.0 \pm 1.9 \\
126.5 \pm 3.2\end{array}$ & $\begin{array}{l}114.4 \pm 0.7^{*} \\
99.0 \pm 1.6^{*}\end{array}$ & $\begin{array}{l}119.8+0.9 \\
114.2 \pm 3.5^{*}\end{array}$ & $\begin{array}{l}122.2 \pm 1.0 \\
125.0 \pm 4.1\end{array}$ \\
\hline $\begin{array}{l}\text { haematocrit } 1 \mathrm{~h} \\
\text { haematocrit } 24 \mathrm{~h}\end{array}$ & $\begin{array}{l}37.3 \pm 1.3 \\
42.8 \pm 2.2\end{array}$ & $\begin{array}{l}42.2 \pm 1.9 \\
60.6 \pm 1.9^{*}\end{array}$ & $\begin{array}{l}39.3 \pm 2.2 \\
46.0 \pm 3.3\end{array}$ & $\begin{array}{l}37.3 \pm 1.5 \\
37.8 \pm 1.4\end{array}$ \\
\hline $\begin{array}{l}\text { plasma } \mathrm{Cl}^{-} \\
24 \mathrm{~h} \text { recov. in } \mathrm{GoT} \\
24 \mathrm{~h} \text { recov. in } \mathrm{W}\end{array}$ & $\begin{array}{l}122.9 \pm 3.0 \\
113.9 \pm 4.9\end{array}$ & $\begin{array}{l}116.9 \pm 3.2 \\
118.6 \pm 3.1\end{array}$ & $\begin{array}{l}128.9 \pm 2.7 \\
117.3 \pm 4.3^{\sharp}\end{array}$ & $\begin{array}{l}125.9 \pm 2.9 \\
114.1 \pm 4.1^{4}\end{array}$ \\
\hline $\begin{array}{l}\text { haematocrit } \\
24 \mathrm{~h} \text { recov. in GoT } \\
24 \mathrm{~h} \text { recov. in W }\end{array}$ & $\begin{array}{l}36.0 \pm 2.2 \\
38.8 \pm 0.9\end{array}$ & $\begin{array}{l}37.3 \pm 1.5 \\
34.3 \pm 2.2\end{array}$ & $\begin{array}{l}34.2 \pm 1.3 \\
36.8 \pm 1.9\end{array}$ & $\begin{array}{l}33.5 \pm 3.8 \\
34.2 \pm 2.7\end{array}$ \\
\hline
\end{tabular}

* : significantly different $(\mathrm{P}<0.05)$ from 'Go group'

\# : significantly different $(\mathrm{P}<0.05)$ from ' $24 \mathrm{~h}$ recov. in GoT group'

$\mathrm{n}=6$, means $\pm \mathrm{SEM}$

Haematocrit increased in fish held in acid water for $24 \mathrm{~h}$ (cage Ne). In the recovery experiment fish were placed for $1 \mathrm{~h}$ in the toxic mixing zone (cage $\mathrm{E}$ ), the end of the mixing channel (cage W), the neutral ( $\mathrm{Go}$ ) or acid ( $\mathrm{Ne}$ ) inlet. Subsequently they were transferred to either cage W or to separate tanks with neutral water (GoT) for $24 \mathrm{~h}$. There was no mortality in the recovery experiments. Fish exposed to cage E restored their 
$\mathrm{Cl}^{-}$levels well in GoT but not in cage W. Fish exposed to cage W maintained their plasma $\mathrm{Cl}^{-}$in GoT but showed a significant drop in cage W. Control fish kept in cage Go reacted similarly to the $\mathrm{W}$ group but the decrease in $\mathrm{Cl}^{-}$was just not significant. Fish kept in cage $\mathrm{Ne}$ for 60 min maintained their low plasma $\mathrm{Cl}^{-}$levels in cage $\mathrm{W}$ and did not recover very well in GoT (neither after $72 \mathrm{~h}$, results not shown) in contrast to the $\mathrm{Cl}^{-}$levels of the other groups. In the recovery experiment there were no significant differences in haematocrit between the different groups.

Electron microscopy of the gills.

In fish exposed for $24 \mathrm{~h}$ to water from lake Gorja (cage Go) the gills showed the normal ultrastructure known for brown trout, and no differences were observed with fish sampled at the hatchery (results not shown). Only few chloride cells (branchial cells specialized for ion exchange) showed signs of degeneration by necrosis or apoptosis (necrosis: accidental cell death, characterized by rupture of membranes and swelling of cell compartments; apoptosis: physiologically controlled cell death, characterized by cellular shrinkage and densification of nuclei, mitochondria and cytoplasm; Wendelaar Bonga et al., 1990). However, in fish from acid water (NE) and from the mixing zone (E) Al deposits on the branchial filaments and severe damage of the branchial epithelium were found. After $24 \mathrm{~h}$ the percentage of necrotic and apoptotic chloride cells was significantly increased (Fig. $1 ; \mathrm{P}<0.01$ ) when compared to the fish from water of lake Gorja. Also many respiratory cells, which form the epithelium covering the respiratory lamellae, showed highly increased percentages of necrotic and apoptotic cells. The intercellular spaces of the branchial epithelia were enlarged in many places, and many leucocytes (many macrophages, lymphocytes and some neutrophilic granulocytes) had left the blood and penetrated into these spaces. In mixed water $340 \mathrm{sec}$ after mixing (W), hardly any $\mathrm{Al}$ deposits nor substantial damage were observed, and the percentages of necrotic and apoptotic chloride cells were not different from control levels (Fig. 1). After $1 \mathrm{~h}$ of exposure, the branchial damage of groups NE and E already was substantial, and hardly less than after $24 \mathrm{~h}$. The percentage of necrotic cells was similar, although the percentage of apoptotic cells was 30$40 \%$ of that observed after $24 \mathrm{~h}$ in these groups. Al deposits were as dense as after $24 \mathrm{~h}$, and enlargement of intercellular spaces and presence of leucocytes in these spaces were hardly less than after $24 \mathrm{~h}$.

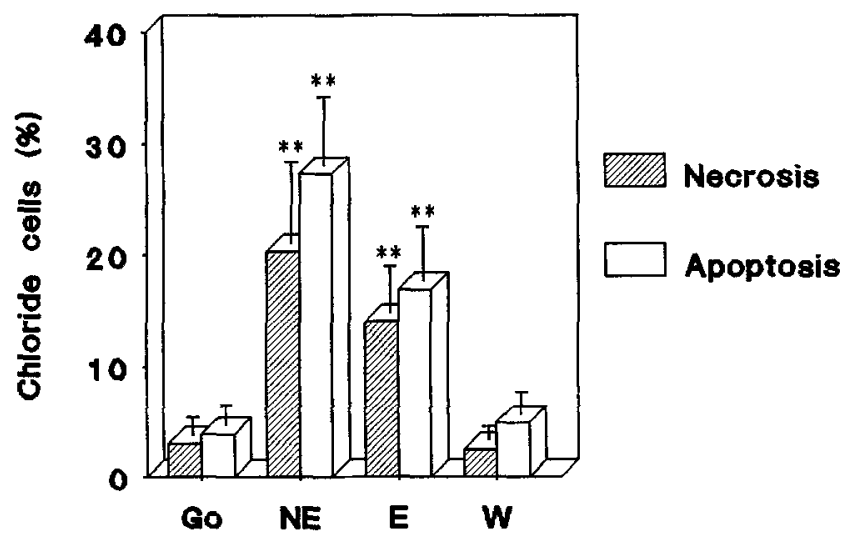

Fig. 1. Percentage of apoptotic and necrotic chloride cells in the gills of trout exposed for $24 \mathrm{~h}$ to neutral water (Go), acid water with $\mathrm{Al}(\mathrm{NE})$, freshly mixed water $(E)$ and mixed water $340 \mathrm{sec}$ after mixing (W); means $\pm \mathrm{SD} ; \mathrm{n}=6$. (** $\mathrm{P}<0.01)$ 
After $24 \mathrm{~h}$ recovery following $1 \mathrm{~h}$ of exposure to freshly mixed water $(\mathrm{E})$, the strucutre of the branchial epithelium was substantially improved in fish that recovered in neutral lake Gorja water, and slightly improved in fish that recovered in cage W. Improvement was observed for all ultrastructural parameters mentioned.

\section{Discussion}

Our results show that freshly mixed acid and neutral waters are toxic to brown trout especially during the first minutes after mixing and this toxic effect can not be explained on the basis of current models on Al toxicity that predict no toxic effect of the metal above $\mathrm{pH} 6$. The acidification was very mild in the mixed water $(\mathrm{pH} \mathrm{6.4)} \mathrm{compared}$ to that in the acid inlet ( $\mathrm{pH}$ 5.1). The reduction in plasma $\mathrm{Cl}^{-}$levels is more drastic in fish kept in the acid inlet (cage $\mathrm{Ne}$ ) than in the first meter of the mixing zone (cage $\mathrm{E}$ ). However, fish in cages further downstream experienced the same $\mathrm{pH}$ as fish in cage $\mathrm{E}$ but did not show any reduction in plasma $\mathrm{Cl}^{-}$. This observation and the microscopical results show that toxicity decreases rapidly with time after mixing. The EM analysis clearly showed that the structural damage to the gill epithelium (necrosis and apoptosis of chloride cells) and infiltration of leucocytes in fish kept in cage $\mathrm{E}$ (beginning of the mixing zone) were comparable to that seen in fish from the acid inlet ( $\mathrm{Ne}$ ).

The artificial channel that was built for this experiment (as in Poleo et al. 1994) simulated a mixing zone as they occur in the field very closely because natural water sources were used. The length of the channel and the flow rate dictated that the time after mixing was maximally $340 \mathrm{sec}$. In other words, the last cage (cage W) was $340 \mathrm{sec}$ away from the confluence. A really un-natural situation is created, however, by keeping the fish at one spot for $24 \mathrm{~h}$ (Table 1, top). When the fish were kept in the toxic mixing zone (cage E) for $1 \mathrm{~h}$ and then moved to a more down stream area (cage $\mathrm{W}$, which is far less toxic than cage $E$ ), thus mimicking a more natural situation of a relatively short encounter with the toxic mixing zone, there was clearly a reduced capacity to restore the damaged gill tissue and plasma $\mathrm{Cl}^{-}$levels when compared to fish recovering in neutral, unmixed water (Got).

The mechanism for the toxicity of the mixing zone is unknown at present. A wide spectrum of metals and ions was determined ( $\mathrm{Fe}, \mathrm{Mn}, \mathrm{Zn}, \mathrm{Ni}, \mathrm{Cu}, \mathrm{Pb}, \mathrm{Ca}, \mathrm{Mg}, \mathrm{Na}, \mathrm{K}, \mathrm{Cl}$ $\mathrm{SO}_{4}, \mathrm{NO}_{3}, \mathrm{~F}$ ) but only $\mathrm{Al}$ levels were in the toxic range. In previous articles of our group reporting on the mixing zone phenomenon a causal relationship between the toxicity and the process of Al-polymerization has been suggested (Rosseland et al., 1992; Salbu et al., 1995). The proposed mechanism was a combination of suffocation by Al-precipitates on the gills and loss of plasma $\mathrm{Na}^{+}$and $\mathrm{Cl}^{-}$by the acidification (Poleo et al., 1994). The essential point made by this kind of studies is that liming of water or mixing of acidic Alrich water with neutral (limed) water leads to a transient toxicity of the water. In this study we found further evidence for toxic effects of these socalled mixing zones that may have negative effects on the survival of migrating trout as indicated by the physiological 
disturbances following a relatively short exposure to the mixing zone. When the fish migrate seaward in spring they will repeatedly encounter mixing zones. It is likely that the young trout will reach the ocean in a weakened state when they have to pass several toxic mixing zones in a river system.

\section{Acknowledgements}

The study was supported by a grant from the EU (EV5V-CT92-0073). P.M. Verbost was supported by a grant from the Dutch Science Foundation (project NBI 22.2832).

\section{References}

Atland, A. and Barlaup, B.T.: 1995, "Avoidance of toxic mixing zones by Atlantic salmon (Salmo salar L.) and brown trout (Salmo trutta L.) in the limed river Audna, Southern Norway", Water, Air Soil Poll. (in press).

Baker, J.P. and Schofield, C.L.: 1982, "Aluminum toxicity to fish in acidic waters", Water, Air Soil Poll. 18, 289-309.

Driscoll, C.T.: 1984, "A procedure for the fractionation of aqueous aluminum in dilute acidic water", Intern. J. Environm. Anal. Chem. 16, $267-283$.

Howells, G.D., Brown, D.J.A. and Sadler, K.: 1983, "Effects of acidity, calcium and aluminum on fish survival and productivity - a review", J. Sci. Food Agric. 34, 559-570.

Muniz, I.P. and Leivestad, H.: 1980, "Toxic effects of aluminium on the brown trout, Salmo trutta", Proc. Int. Confer. Ecol. Impact Acid Precip. - SNSF project Norway, $320 \mathrm{pp}$.

Poleo, A.B.S., Lydersen, E., Rosseland, B.O., Kroglund, F., Salbu, B., Vogt, R.D. and Kvellestad, A.: 1994, "Increased mortality of fish due to changing Al-chemistry of mixing zones between limed streams and acidic tributaries", Water, Air Soil Poll. 75, 339-351.

Rosseland, B.O., Blakar, I.A., Bulger, A., Kroglund, F., Kvellstad, A, Lydersen, E., Oughton, D.H., Salbu, B., Staurnes, M. and Vogt, R.: 1992, "The mixing zone between limed and acidic river waters: complex aluminum chemistry and extreme toxicity for salmonids", Environm. Pollut. $78,3-8$.

Salbu, B., Lydersen, E., Rosseland, B.O., Kroglund, F., Oughton, D.H., Poleo, A.B.S., Riise, G., Wendelaar Bonga, S.E., Verbost, P.M., Heydorn, K., Exley, C., Witters, H., Van Puymbroeck, S. and Hektoen, H.: 1995, "Polymerization of aluminum and acute fish toxicity in mixing zones with $\mathrm{pH}$ above 6", Environm. Sci. Technol., submitted.

Verbost, P.M., Lafeber, F.P.J.G., Spanings, F.A.T., Aarden, E.M. and Wendelaar Bonga, S.E.: 1992 , "Inhibition of $\mathrm{Ca}^{2+}$ uptake in freshwater carp, Cyprinus carpio, during short-term exposure to aluminum", J. Exp. Zool. 262, 247-254.

Wendelaar Bonga, S.E., Flik, G., Balm, P.H.M. and Meij, J.C.A. van der: 1990, "The ultrastructure of chloride cells in the gills of the teleost Oreochromis mossambicus during exposure to acidified water", Cell Tissue Res. 259, 575-585

Zall, D.M., Fisher, D. and Garner, M.Q.: 1956, "Photometric determination of chlorides in water", Analyt. Chem. 28, 1665-1668. 